Agro-Science Journal of Tropical Agriculture, Food, Environment and Extension Volume 19 Number 1 (January 2020) pp. 18 - 24

ISSN 1119-7455

\title{
EFFECT OF MALTING PERIODS ON THE NUTRIENT COMPOSITION, ANTINUTRIENT CONTENT AND PASTING PROPERTIES OF MUNGBEAN FLOUR
}

\author{
${ }^{* 1}$ Onwurafor E.U., ${ }^{2}$ Uzodinma E.O., ${ }^{2}$ Uchegbu N.N., ${ }^{2}$ Ani J.C., ${ }^{2}$ Umunnakwe I.L. and ${ }^{3}$ Ziegler G. \\ ${ }^{1}$ Centre for Entrepreneurship \& Development Research, ${ }^{2}$ Department of Food Science \& Technology, \\ University of Nigeria, Nsukka 410001, Nigeria \\ ${ }^{3}$ Pennsylvania State University, Department of Food Science, University Park, PA 16802, USA
}

*Corresponding author's email: eucharia.onwurafor@unn.edu.ng

\begin{abstract}
Mungbean grain has great potentials for product development, being rich in protein and other nutrients. This study evaluated the effects of malting periods on the nutrient composition, antinutrient content and pasting properties of malted mungbean flour. Flour samples were produced form mungbean grain malted for 24, 48, 72 and $96 h$ and assayed for proximate composition, selected mineral contents, vitamins $A$ and B1, antinutrient contents, functional and pasting properties. Results showed that increasing the malting periods of mungbean grain significantly $(p<0.05)$ increased the protein, ash, fibre and mineral contents but decreased fat and carbohydrate contents of its flour. Oil absorption capacities increased while bulk density, swelling and water absorption capacity decreased significantly $(p<0.05)$ with increasing time of malting. Extending time of malting gave flours with reduced antinutrient, peak, trough, final and setback viscosities and pasting time but higher pasting temperature compared to unmalted flour. The study has shown that malting period modifies the nutrient composition, antinutrient contents and functionality of mungbean flour differently and invariably may affect the performance of the flour in product development. Mungbean grain malted at $72 \mathrm{~h}$ gave flour with highest quality establishing its optimal malting period at $72 \mathrm{~h}$.
\end{abstract}

Key words: malting, nutrient composition, 'orarudi', pasting-properties, mungbean

\section{INTRODUCTION}

Legumes occupy an important position in the diets of people in developing countries because they are rich sources of protein, minerals and vitamins and can be used to supplement their staples which are majorly carbohydrate based. El Maki et al. (2007) reported that legumes are major contributors of protein in most African diets, but some of such legumes are unconventional and under-exploited. Such unconventional legumes have been associated with some bioactive compounds that can impact human health hence the need to study them. Among such unconventional legumes, is mungbean spp. locally known as 'orarudi'. Mungbean has high nutritional potentials (Mensah and Olukoya, 2007). Like most legumes, mungbean is rich in protein and essential amino acids, with exception of sulphur-containing amino acids (Khalil, 2006). Mungbean protein is rich in lysine but deficient in methionine (Anderson, 2007). There is a paucity of information on the use of mungbean malt in product formulation or value-added products in Nigeria particularly in infant foods. Mungbean grains like other legumes contain certain antinutritional factors (including polyphenols and phytic acid) beside high viscosity which may limit their flour utilization in product formulation (Sandhul and Lim, 2007; Makumba et al., 2016). It is therefore, pertinent to develop strategies to process the underutilized indigenous crops into flours of high nutritional quality and functionality that can be used in product development.

One of the simple traditional technologies adopted for improving the nutrient composition and functionality of plant foods is malting. Malting is controlled germination followed by controlled drying of the germinated kernels. Malting plays a significant role in promoting the development of hydrolytic enzymes, which are not present in nongerminated grains. It improves both the nutritional and functional properties of legumes (Mensah and Tomkins, 2003) and allows preparation of low-bulk foods through elaboration of amylases resulting in reduced viscosity of the gelled germinated starch (Brandtzaeg et al., 1981; Kulkarni et al., 1991). Low bioavailability of nutrients arising from the presence of antinutrients such as phytate, polyphenols, and oxalate, could limit the quality of predominantly plant-based diets. Uppal and Brains

Please cite as: Onwurafor E.U., Uzodinma E.O., Uchegbu N.N., Ani J.C., Umunnakwe I.L. and Ziegler G. (2020). Effect of malting periods on the nutrient composition, antinutrient content and pasting properties of mungbean flour. Agro-Science, 19 (1), 18-24. DOI: https://dx.doi.org/10.4314/as.v19i1.3 
(2012) reported that malting could significantly raise the bioavailability of nutrients. Malleshi and Klopfenstein (1996) also reported that malting of grains increased protein and carbohydrate digestibility, enhance some of their vitamin contents, reduce antinutritional factors and improves their overall nutritional quality. The nutritional composition and antinutritional factors of mungbean seeds (Phaseolus aureus) as affected by some home traditional processes was also reported by Mubarak (2005).

Presently, utilization of malted legume flour like its cereals counterpart is gaining height in product development in developing countries and establishing their optimal malting period to obtain best flour becomes necessary. Kaur et al. (2018) reported that starches from different cereal exhibit different pasting and functional properties, however flours developed from legumes malted at different periods may perform differently in product development also and needed some investigation. According to Onwurafor et al. (2017, substitution of cereal flour with malted legume flour gave products of higher quality and better functional properties. Savelkoul et al. (1992) reported that the effect of germination depends on the conditions and duration of germination process. Research on the malting of legumes such as bambara groundnut, soyabean among others have been done. However, there is dearth of information in this regard of this specie of mungbean grain 'orarudi', necessitating research effort. For efficient utilization of the flour of malted mungbean flour, there is need to study the nutrient composition, antinutrient content as well as pasting properties in order to know the food system it can be applied in. Hence, this study evaluated the effects of malting periods on the nutrient composition, antinutrient content and pasting properties of mungbean flour.

\section{MATERIALS AND METHODS}

Mungbean grains (Vigna radiata) were purchased from Orba market in Nsukka Local Government Area, Enugu State, Nigeria. Identification of the crop was done in the Department of Crop Science, University of Nigeria, Nsukka.

\section{Processing of Mungbean Grain into Flour}

Five lots of sorted mungbean grain (200 g each) were weighed into porous bags $(25 \mathrm{~cm} \times 45 \mathrm{~cm})$ and steeped in water for $3 \mathrm{~h}$, air rested for $90 \mathrm{~min}$. and re-steeped in fresh tap water for $3 \mathrm{~h} \mathrm{(a}$ modification of the two-step wet-steep method of Etok-Akpan and Palmer (1990). The steeping schedule was based on the time for maximum water absorption characteristics of the mungbean seed (Umunnakwe, 2012). One lot of mungbean seeds was wet dehulled. The second, third, fourth and fifth lots of $200 \mathrm{~g}$ of grain each was spread in a dark room to germinate for $24,48,72$ and $96 \mathrm{~h}$, respectively, during which they were, turned every $24 \mathrm{~h}\left(30 \pm 0.2{ }^{\circ} \mathrm{C}\right)$. The samples were moistened on alternate days by dipping the malting bags containing the germinating grains in water for 30 sec. One lot (bag) was picked at interval of 24, 48, 72 and $96 \mathrm{~h}$. The wet dehulled sample and green malts were dried at $50{ }^{\circ} \mathrm{C}$ for $12 \mathrm{~h}$ and then separated from the sprouts and hulls by abrasion between the palms followed by winnowing. Subsequently, each lot was milled using a Bentall attrition mill (Model 200 L090, E. H. Bentall U.K), sieved through $200 \mu \mathrm{m}$ sieve and stored in polyethylene bags at $4{ }^{\circ} \mathrm{C}$ until use for analyses.

\section{Determination of Proximate Composition, Minerals, Vitamins and Antinutrients}

Mungbean malt flour was analyzed for proximate composition (moisture, crude protein, fat, fibre and ash) using AACC (2000) methods. Protein content of the samples was calculated using the formula, protein=nitrogen $\times 6.25$ Carbohydrate was estimated by difference $(100-\%$ protein $+\%$ ash + $\%$ fat $+\%$ crude fibre $+\%$ moisture) and the values converted to $\mathrm{g} / 100 \mathrm{~g}$ sample. Each analysis was carried out in three replications. Calcium, iron, zinc, phosphorous, potassium, sodium, magnesium and copper contents of the malt flour were determined using inductively coupled plasma atomic absorption spectrophotometer (AACC, 2000). The processed flours were analyzed for provitamin A content according to the methods described by Arroyave et al. (1982) and converted to retinol equivalent. Vitamin B1 was determined according to the methods of AOAC (2010). Tannin, oxalate and phytate contents of the processed flours were determined according to the methods described by Burns (1971), Fassett (1973) and Latta and Eskin (1980), respectively.

Determination of $\mathbf{p H}$, Titratable Acidity, Functional and Pasting Properties

The $\mathrm{pH}$ and titratable acidity were carried out using the methods described by AACC (2000). Swelling capacity was determined according to the methods described by Takashi and Sieb (1988) while water absorption and oil absorption capacity of the flour was determined by methods of AACC (2000). The bulk density was determined by the methods described by Okaka and Potter (1979). Pasting properties; peak (PV), trough (TV), breakdown (BD), final $\mathrm{V}(\mathrm{FV})$ and setback (SB) viscosities, peak time and pasting temperature of malted and unmalted flours were determined using Rapid Visco-Analyzer (Newport Scientific, PTY.LTD, Australia) connected to a computer (PC) with Windows $^{\mathrm{TM}}$ operating system via a USB port according to the methods described by Newport 
Scientific Method (1998). The moisture content of the flour was first determined to obtain the correct sample weight and amount of water required for the test. An aqueous suspension of sample was then made by mixing $3 \mathrm{~g}$ sample in $25 \mathrm{~mL}$ of distilled water and spun at $75 \mathrm{rpm}$. The temperature-time conditions included a heating step from 50 to $95{ }^{\circ} \mathrm{C}$ at $6{ }^{\circ} \mathrm{C} / \mathrm{min}$ (after an equilibrium-time of $1 \mathrm{~min}$. at $50{ }^{\circ} \mathrm{C}$ ), a holding phase at $95{ }^{\circ} \mathrm{C}$ for 5 min., a cooling step from 95 to $50{ }^{\circ} \mathrm{C}$ for 2 min. Viscosities were expressed in rapid viscosity units (RVU).

\section{Statistical Analysis}

Data were subjected to one-way analysis of variance (ANOVA) (Steel and Torrie, 1980). Mean separation was done by Duncan New Multiple Range Test using SPSS version 16.00 software, with $p$ set at $<0.05$.

\section{RESULTS AND DISCUSSION \\ Proximate Composition of Mungbean Malted at Different Periods}

Figures 1a-f show the change in proximate composition of the flours of mungbean seeds malted at different periods. Moisture content increased as the malting period increased (Figure 1a). This observation is attributable to hydration of the seeds during steeping and germination. Also, since starch and proteins are broken down during germination, the sorption isotherm will be changing so that it may attract more water. Oluwole et al. (2012) attributed similar observation during malting of sorghum and maize grain to prolonged addition of water. A similar increase was observed in protein content of the flour with increase in malting period (Figure 1b). However, the protein content decreased after $72 \mathrm{~h}$. The breakdown of complex proteins into simpler forms and/or reduction of other components such as carbohydrates and fats in the malts as reported by other researchers (Mubarak, 2005) may have given rise to the observed effect on protein content with increase in malting period. The protein value observed in the malts were higher than values from processed sunflower seeds (Adesina, 2018).

Progressive reduction of fat content of mungbean flour was observed as malting period was increased (Figure 1c). Flour sample malted for $96 \mathrm{~h}$ had the lowest fat content. The lower fat content of malted sample compared to the value of the unmalted flour (Figure 1c) agrees with the findings of Mubarak (2005). The use of fat as an energy source and increased activities of the lypolytic enzymes during malting which hydrolyzed fats to fatty acids and glycerol may explain the decrease in fat content. This shows that increase in malting period increases consumption of fat and the activities of lypolytic enzyme. However, an increase in fat content of soybean germinated for 1-6 days has been reported (Kayembe and Jansen van Rensburg, 2013).
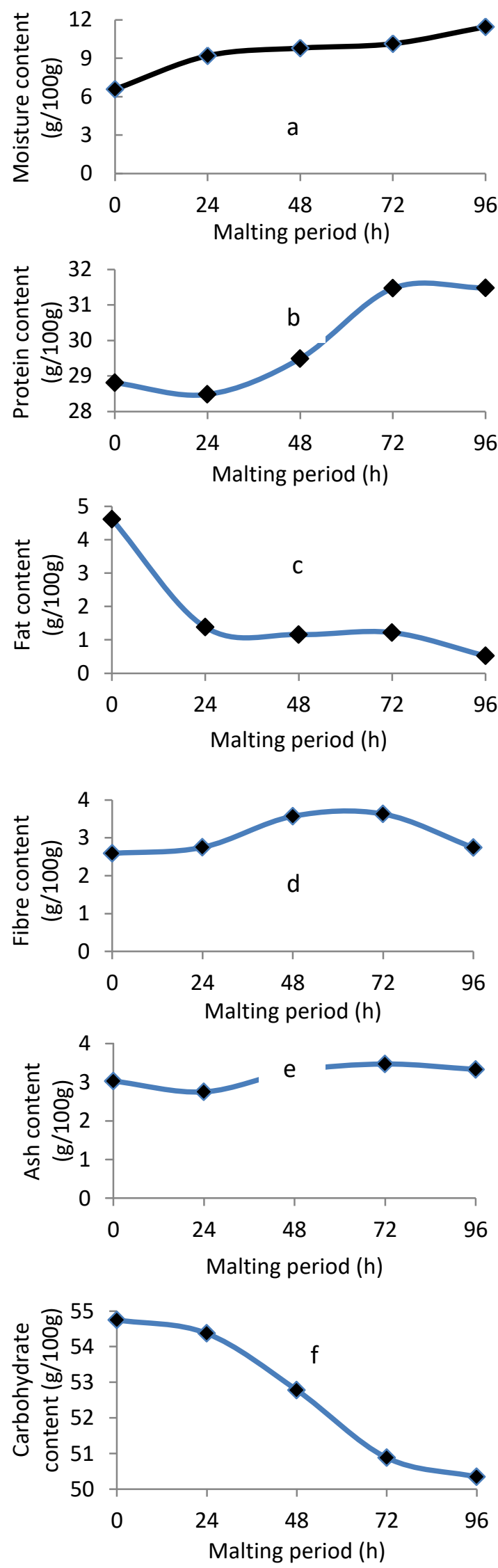

Figures 1 a, b, c, d, e and f: Proximate composition $(\mathrm{g} / 100 \mathrm{~g})$ of mungbean malted at different periods 
Both fibre and ash contents of the mungbean malt (Figure $1 \mathrm{~d}$ ) significantly $(p<0.05)$ increased with malting period with highest values in samples malted for $72 \mathrm{~h}$ (Figure 1e). The result agrees with Chikwendu (2003) who attributed ash increase to endogenous hydrolysis of complex organic compounds which released more nutrients. On the contrary, the findings of Oluwole et al. (2012) and Muhammed et al. (2012) reported decreases in ash content during malting of sorghum and barley due to differences in seed composition. Lowest content of carbohydrate was observed in $96 \mathrm{~h}$ malt indicating that carbohydrate decreased with malting period. The decrease in carbohydrate and fat may have caused the increase in ash content of the samples as the malting period increased. Carbohydrate content decreased with malting period probably due to carbohydrate use as energy source for sprouting (Mubarak, 2005). Kirk-Othmer (2007) reported that malting affected carbohydrate molecules in germinating grains through the action of amylase whereby the carbohydrates were reduced to maltodextrins and low molecular weight sugars.

\section{Minerals, Vitamin A and B1 Contents of Mungbean Malted at Different Periods}

The values of calcium and iron increased as the malting period increased (Table 1). Malting for 72 $h$ showed highest increase in calcium contents, the value finally decreased in the $96 \mathrm{~h}$ malted sample. The increase in mineral level with malting period increase may be due to concentration. Calcium and iron contents increase during malting of beans were earlier reported by Muhammad (1990). The K, P, and $\mathrm{Mg}$ contents of mungbean malt increased also as the malting period increased with $72 \mathrm{~h}$ malt having the highest values (1376.78, 312.99 and $187.31 \mathrm{mg} / 100 \mathrm{~g}$ for $\mathrm{K}, \mathrm{P}$ and $\mathrm{Mg}$, respectively).

In contrast, zinc and sodium contents decreased for the first $48 \mathrm{~h}$ and then increased as malting period was increased to $72 \mathrm{~h}$. The unmalted sample had higher zinc content $(5.16 \mathrm{mg} / 100 \mathrm{~g})$ compared to 24,48 , and $96 \mathrm{~h}$ malt $(4.71,4.60$ and 3.82 $\mathrm{mg} / 100 \mathrm{~g}$, respectively) which increased at the $72 \mathrm{~h}$ of malting. The decrease in zinc content at the initial stage $\left(24^{\text {th }}\right.$ and $\left.48^{\text {th }} \mathrm{h}\right)$ could be due to the use of zinc in cell reproduction and tissue growth (Scherz and Kirchhoff, 2006). Zinc deficiency causes growth retardation and inadequate sexual development in human (Wardlaw and Kessel, 2002). The result indicates that mungbean malt is a good source of iron and zinc being significant at this time that iron and zinc deficiencies are among public health concern. The vitamin $\mathrm{A}$ as retinol equivalent $(\mathrm{Re})$ and vitamin $\mathrm{B}_{1}$ contents of the processed mungbean malt sample are also shown in Table 1. Vitamin A content of mungbean samples increased as the malting period increased. The non malted flour was found to have the least vitamin A content $(43.7 \mu \mathrm{gRE} / 100 \mathrm{~g})$ while mungbean sample malted for $96 \mathrm{~h}$ had the highest vitamin A content (163.8 $\mu \mathrm{gRE} / 100 \mathrm{~g})$. The increases in vitamin A (as retinol equivalent) with increasing malting period suggested that higher synthesis and/extractability of $\beta$-carotene occurs as the time of malting increased. Vitamin $B_{1}$ follows the same trend. Vitamin $\mathrm{B}_{1}$ (thiamin) content of the processed mungbean flour ranged from 4.6 to 10.05 $\mathrm{mg} / 100 \mathrm{~g}$. It was observed that vitamin $\mathrm{B}_{1}$ increased as malting period increased. Non-malted flour had the least vitamin $B_{1}$ content while mungbean sample malted for $96 \mathrm{~h}$ had the highest vitamin $\mathrm{B}_{1}$ content. Germination has been reported to increase vitamin $B_{1}$ (Nzelibe and Onyeniran, 2001).

\section{Anti-nutrient Contents of Mungbean Malted at Different Periods}

Length of malting affected the quantity of tannin, phytate and oxalate in the mungbean malt flour positively (Figure 2). The tannin, phytate and oxalate contents of mungbean malt flour decreased as the period of malting was increased. The decrease observed in these parameters was significant $(p<0.05)$. However, a marginal increase in tannin content was observed in the 72 and $96 \mathrm{~h}$ malted samples. The decrease in phytate contents could be attributed to increased activity of phytase due to increase in malting periods that progressively degraded phytic acid. These results corroborate Pawar and Machewad (2006) who attributed the reduction of phytate to phytic acid degradation by phytase synthesized during the process.

Table 1: Changes in selected mineral contents of mungbean during malting

\begin{tabular}{|c|c|c|c|c|c|}
\hline \multirow{2}{*}{ Parameter $(\mathrm{mg} / 100 \mathrm{~g})$} & \multicolumn{5}{|c|}{ Malting period $(\mathrm{h})$} \\
\hline & 0 & 24 & 48 & 72 & 96 \\
\hline Calcium & $98.46^{\mathrm{b}} \pm 0.69$ & $100.52^{\mathrm{b}} \pm 0.01$ & $101.74^{\mathrm{c}} \pm 0.02$ & $122.00^{\mathrm{e}} \pm 0.79$ & $102.98^{\mathrm{b}} \pm 0.91$ \\
\hline Zinc & $5.16^{\mathrm{c}} \pm 0.03$ & $4.71^{\mathrm{c}} \pm 0.12$ & $4.60^{\mathrm{b}} \pm 0.00$ & $5.31^{\mathrm{d}} \pm 0.00$ & $3.82^{\mathrm{a}} \pm 0.00$ \\
\hline copper & $0.73^{\mathrm{a}} \pm 0.00$ & $0.73^{\mathrm{a}} \pm 0.00$ & $0.78^{\mathrm{a}} \pm 0.01$ & $0.92^{\mathrm{c}} \pm 0.02$ & $0.79^{\mathrm{ab}} \pm 0.00$ \\
\hline Sodium & $5.47^{\mathrm{b}} \pm 0.17$ & $5.26^{\mathrm{b}} \pm 0.03$ & $5.11^{\mathrm{a}} \pm 0.01$ & $7.07^{\mathrm{d}} \pm 0.020$ & $5.63^{\mathrm{c}} \pm 0.04$ \\
\hline Magnesium & $147.03^{\mathrm{a}} \pm 0.507$ & $147.54^{\mathrm{a}} \pm 0.06$ & $166.42^{\mathrm{b}} \pm 0.56$ & $187.31^{\mathrm{c}} \pm 0.50$ & $165.15^{\mathrm{b}} \pm 0.00$ \\
\hline Vitamin A $(\mu g R E / 100 g)$ & $43.7^{\mathrm{a}} \pm 0.02$ & $54.6^{\mathrm{a}} \pm 0.00$ & $65.5^{\mathrm{b}} \pm 0.00$ & $109.2^{\mathrm{d}} \pm 0.00$ & $163.8^{\mathrm{e}} \pm 0.00$ \\
\hline Vitamin B1(mg/100g) & $4.6^{\mathrm{b}} \pm 0.01$ & $5.3^{\mathrm{b}} \pm 0.00$ & $6.7^{\mathrm{c}} \pm 0.00$ & $7.7^{\mathrm{d}} \pm 0.02$ & $10.05^{\mathrm{e}} \pm 0.01$ \\
\hline
\end{tabular}




\section{Functional Properties of Mungbean Malt Flour Malted at Different Periods}

There were significant $(p<0.05)$ differences in the water absorption capacity of all the samples (Table 2). Increasing the malting time significantly $(p<0.05)$ decreased the water absorption capacity and bulk density (BD) of the sample. Decrease in water absorption capacity as malting period increased may be due to hydrolysis of starch polymer (Adebowale et al., 2005) caused by malting effect or variation of protein content of mungbean malt that denatured during processing; this may affect the amount of water absorbed (Omeire et al., 2014). Protein may be hydrolyzed during germination to release free amino acids and these would bind water more effectively.

Swelling capacity of the mungbean flour samples varied from 0.553 to $0.763 \mathrm{~g} / \mathrm{ml}$ and significantly $(p<0.05)$ decreased with increasing malting period. Differences in the friability of the materials caused by differences in malting period gave rise to variation in bulk density. However, there was marginal decrease in swelling capacity until the $48^{\text {th }} \mathrm{h}$, then significant $(p<0.05)$ decrease was seen in 72 and $96 \mathrm{~h}$ malted flour. Swelling capacity influenced other functional properties of starchy product which in turn determine their suitability in product development (Amajor et al., 2014). Generally, the low swelling capacity observed in the study could be due to malting effect caused by high amylose content of mungbean malt flour. Adebowale et al. (2005) noted that high amylose content could result in low swelling index. Increasing malting period may have effect on the starch component of the flour which may be caused by high amylose content of mungbean malt as noted earlier thus leading to reduction of swelling capacity. On the contrary, Kaur et al. (2018) observed higher swelling capacity in isolated cereal starches implying that cereal starch swells better than legume. Difference in structure of starch granules between cereals and legumes and /or pure starch in relation to whole grain flour may cause flour to swell differently. In contrary, oil absorption capacity increased with malting periods. Oil absorption capacity indicates the ability of the sample to retain flavor and improve mouth-feel (Kinsella, 1976). From the study, flour malted for longer period may have better flavor retention and mouth feel when developed into product.

Table 2: Some functional properties of mungbean malt flour

\begin{tabular}{lcccc}
\hline $\begin{array}{l}\text { Malting } \\
\text { Period } \\
(\mathrm{h})\end{array}$ & $\begin{array}{c}\text { WAC } \\
(\mathrm{ml} / 100 \mathrm{~g})\end{array}$ & $\begin{array}{c}\text { Bulk } \\
\text { density } \\
(\mathrm{g} / \mathrm{ml})\end{array}$ & $\begin{array}{c}\text { Swelling } \\
\text { capacity } \\
(\mathrm{ml} / \mathrm{g})\end{array}$ & $\begin{array}{c}\text { OAC } \\
(\mathrm{ml} / 100 \mathrm{~g})\end{array}$ \\
\hline 0 & $153.00^{\mathrm{d}} \pm 0.11$ & $0.763^{\mathrm{d}} \pm 0.01$ & $0.763^{\mathrm{c}} \pm 0.62$ & $164^{\mathrm{a}} \pm 0.03$ \\
24 & $147.00^{\mathrm{d}} \pm 0.06$ & $0.732^{\mathrm{c}} \pm 0.02$ & $0.741^{\mathrm{c}} \pm 0.87$ & $188^{\mathrm{a}} \pm 0.03$ \\
48 & $140.00^{\mathrm{bc}} \pm 0.10$ & $0.706^{\mathrm{bc}} \pm 0.01$ & $0.706^{\mathrm{c}} \pm 0.13$ & $173^{\mathrm{a}} \pm 0.12$ \\
72 & $133.33^{\mathrm{ab}} \pm 0.06$ & $0.693^{\mathrm{b}} \pm 0.01$ & $0.693^{\mathrm{b}} \pm 0.07$ & $233^{\mathrm{b}} \pm 0.12$ \\
96 & $129.00^{\mathrm{a}} \pm 0.05$ & $0.627^{\mathrm{a}} \pm 0.03$ & $0.553^{\mathrm{a}} \pm 0.02$ & $247^{\mathrm{b}} \pm 0.23$ \\
\hline \multicolumn{5}{l}{ Values are means $(n=3) \pm$ SD. Means on the same column carrying } \\
different superscripts are significantly ( $p<0.05)$ different; \\
WAC - water absorption capacity; OAC - oil absorption capacity
\end{tabular}

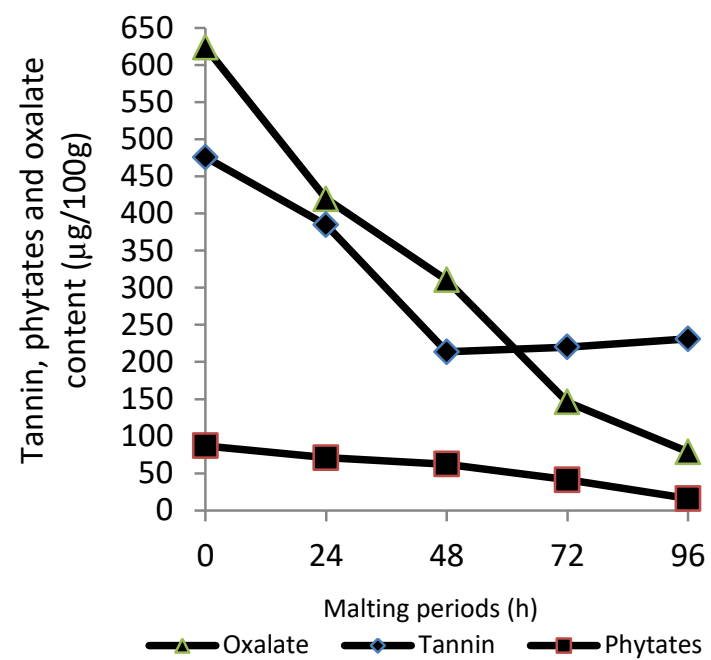

Figure 2: Anti-nutrient contents of mungbean malted at different periods

\section{Pasting Properties of Mungbean Malt Flour Malted at Different Periods}

Figure 3 shows the pasting properties of flour from mungbean grain malted at different periods. Unmalted mungbean malt flour was characterized with high peak viscosity (541 RVU), trough viscosity (386 RVU), final viscosity (647 RVU) and set viscosity (260 RVU) compared to malted samples. Extending malting periods significantly $(p<0.05)$ reduced the aforementioned properties. Bulk density viscosity was highest in $24 \mathrm{~h}$ malted sample. Increasing the malting periods resulted to significant $(p<0.05)$ decrease in peak viscosity $(\mathrm{PV})$, trough viscosity (TV), final viscosity (FV) and setback (SB). The sample malted for $72 \mathrm{~h}$ had the lowest peak viscosity value.

The variation in peak viscosity values of flour samples obtained at different malting periods indicated that malting period confers different degree of gelatinization and affects the amylose content of the flour (Ayinde et al., 2012). Longer malting period may confer higher gel strength and tendency to the flour during cooking or reconstitution but also low reconstituted gel stability contrary to the report of Kaur et al. (2018) on starch isolated from six major cereal with higher peak viscosity (PV) values. The low final viscosity observed in the samples malted for 72 and $96 \mathrm{~h}$ indicated that extending period of malting may cause samples to form a low viscous paste rather than thick gel on cooking thus bring about thinning effects desired in certain products. The setback (SB) values suggest that increasing malting period would result to low retrogradation tendency and syneresis of the flour samples during freeze-thaw process. It was observed that the pasting temperature (PT) increased from $80.95{ }^{\circ} \mathrm{C}$ in non-malted flour sample to $91.90{ }^{\circ} \mathrm{C}$. Increasing the malting period increased the pasting temperature and decreased the 


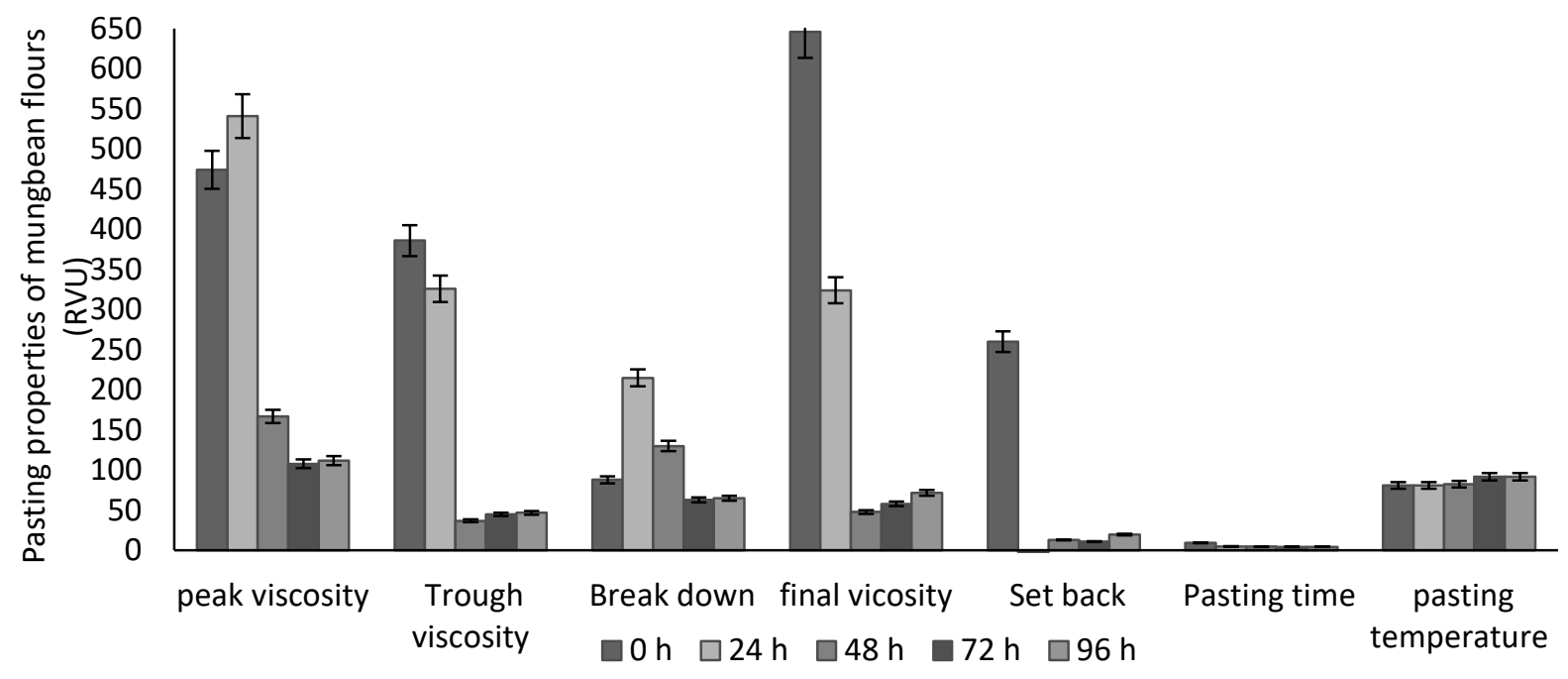

pasting time. Inability of the flours to absorb water easily and swell due to malting periods could have increased the PT. On the contrary, Kaur et al. (2018) reported lower pasting temperature of most isolated pure cereals and attributed it to high water holding capacity of the starches. The PT was reported to be affected by starch concentration. Generally, high gelatinization temperature was observed in this study compared to values reported in literature for cereal starches and composite flour by some earlier researchers (deMan, 1999; Adeguwa et al., 2012; Onwurafor et al., 2017; Kaur et al., 2018). This indicated that the semi-crystalline nature of starch granules in mungbean flour malted at different periods will lose their birefringence differently and at higher temperature than those of pure cereal starches (Kaur et al., 2018). Unmalted sample had the highest cooking time, an indication that higher energy is needed to break the intermolecular bonds in starch granules of this flour to achieve gelatinization compared to malted sample (Kaur and Singh, 2006). This implies that increasing malting period may cause reduction in cooking time of flour, hence reduction in energy cost.

\section{CONCLUSION}

Malting of mungbean grains for different periods confer different properties to its flour in terms of nutrient composition, functional and pasting properties. Malting of mungbean grains up to $72 \mathrm{~h}$ increased the pasting temperature but reduced the cooking time. The optimal malting period for the mungbean grains was $72 \mathrm{~h}$ which had the highest content of most nutrients. The findings of this study could be applied at the rural community level to improve the nutrient and functional properties of the flours for use in product development.

\section{ACKNOWLEDGEMENT}

The authors wish to acknowledge the USDA through the Norman E. Borlaug Fellowship Programme in Pennsylvania State University, USA that gave access to some facilities for part of this research work.

\section{REFERENCES}

AACC (2000). AACC Approved Methods of Analysis. 10th ed. St. Paul, MN: American Association of Cereal Chemists

Adebowale A.A., Sanni L.O. and Awonorin S.O. (2005). Effect of texture modifiers on the physicochemical and sensory properties of dried fufu. Food Sci. Tech. Intl., $11(5), 373-382$

Adegunwa M.O., Bakara H.A., Alamu E.O. and Abiodun O.K. (2012). Processing effects on chemical, functional and pasting properties of cowpea flour from different varieties. NIFOJ, 30 (1), 67-73

Adesina S.A. (2018). Effect of processing on the proximate composition of sunflower (Helianthus annuus) seeds. Agro-Science, 17 (3), 27-33

Amajor J.U., Oti E., Ekeledo N., Omodamiro R., Amajor E.E. and Aniedu C. (2014). Studies on the characteristic Properties of Fermented, Sun-Dried Orange- Fleshed Sweet Potato Flour. NIFOJ, 32 (1), 45-53

American Association of Cereal Chemists (AACC). (2000). AACC Approved Methods of Analysis. 10th ed. St. Paul, MN: American Association of Cereal Chemists

Anderson P. (2007). Report on the nutritive value of Rice bean. European Commission $6^{\text {th }}$ Framework Programme, Food security through Ricebean Research in India and Nepal (FOSRIN). Report 3. Nutritional qualities of rice bean, (pp.1-9), Bergen, Norway,

AOAC (2010). Official Methods of Analysis, Association of Analytical Chemists, (18 $8^{\text {th }}$ ed.) Gaithersburg, Maryland, U.S.A.

Arroyave G., Chichester C.O., Hernando F., Glover J., Mejia L.A., Olson J.A et al. (1982). Biochemical Methodology for the Assessment of Vitamin A Status. (pp. 24-30). The Nutrition Foundation, Washington, DC

Ayinde F.A., Bolaji O.T., Abdus-Salaam R.B. and Osidipe O. (2012). Functional properties and quality evaluation of "kokoro" blended with beniseed cake (Sesame indicum). Afr. J. Fd. Sci., 6 (5), 117-129

Brandtzaeg B., Malleshi N.G., Svanberg U., Desikachar H.S.R. and Mellander O. (1981). Dietary bulk as a limiting factor for nutrient intake-with reference to the feeding of preschool children III: studies of malted flour from ragi, sorghum and green gram.J. Trop. Pediatr., 27, 184-189

Burns R.E. (1971). Methods of Estimation of tannins in the grain sorghum. Agron. J., 63, 517- 519 
Chikwendu N.J. (2003). The effects of germination on the chemical composition and microbial quality of groundbean (Kerstingiella geocarpa) flours. Nig. J. Nutr., 24, 17-22

deMan J.M. (1999). Carbohydrates. In: Principle of Food Chemistry, $3^{\text {rd }}$ ed. (pp. 163-208). Springer Science + Business Media Inc India

El-Maki H.B., Abdel-Rahman S.M., Idris W.H., Hassan A.B., Babiker E.E. and El-Tinay A.H. (2007). Content of antinutritional factors and $\mathrm{HCl}$-extractability of mineral from white bean (Phaseolus vulgaris). cultivars: influence of soaking and/or cooking. $F d$. Chem., 100, 342-362

Etok-Akpan O.U. and Palmer G.H. (1990). A simple diamylase procedure for estimation of $\alpha$-amylase and diastatic activity. J. Inst. Brew., 96, 89-91.

Fasset D.W. (1973). Oxalates. In: Toxicants Occurring Naturally in Foods, $2^{\text {nd }}$ ed. (pp. 346-36), National Academy of Sciences Press, Washington DC

Gill B.S. and Karwasra B.L. (2018). In vitro digestibility, pasting and structural properties of starches from different cereals. Int. J. Food Prop., 9, 70-85

Kaur M. and Singh N. (2006). Relationships between selected properties of seeds, flours, and starches from different chickpea cultivars. Int. J. Fd. Prop., 9, 597-608

Kaur H., Gill B.S. and Karwasra B.L. (2018). In vitro digestibility, pasting and structural properties of starches from different cereals. Int. J. Fd. Prop., 21 (1), 70-85

Kayembe N.C. and Jansen van Rensburg C. (2013). Germination as a processing technique for soybeans in small-scale farming. South-Afr. J. Anim. Sci., 43 (2), 167-173

Khalil A.A. (2006). Nutritional improvement of Egyptian breed of mungbean by probiotic lactobacilli. Afr. J. Biotechnol., 5, 206-212

Kinsella J.E. (1976). Functional properties of proteins in foods. Crit. Rev. Fd. Sci. Nutr., 1 (3), 219-280

Kirk-Othmer O. (2007). Food and Feed Technology. New York: Willey-Interscience. pp. 116-120

Kulkarni K.D., Kulkarni D.N. and Ingle U.M. (1991). Sorghum malt based weaning food formulations: preparation, functional properties and nutritive value. Fd. Nutr. Bull., 13, 322-327

Latta M. and Eskin M. (1980). A simple and rapid colorimetric method of phytate determination. $J$. Agric. Fd. Chem., 29, 315-317

Makumba C.T., Patrick B.N., Oluwafemi A.A., Adetola O.O. and Eugenie K. (2016). The role of compositing cereals with legumes to alleviate protein energy malnutrition in Africa. Int. J. Fd. Sci. Tech., 51 (3), 543-554

Malleshi N.G. and Klopfenstein C.F. (1996). Proximate composition, amino acid and vitamin contents of malted chickpea, mungbean and their seed coats. $J$. Fd. Sci. Technol., 33, 479- 482

Mensah J.K. and Olukoya R.T. (2007). Performance of mungbean (Vigna mungo L) Hepper) grown in midwestern Nigeria. Am-Euras J. Agric. Environ. Sci., 2, 696-701

Mensah P. and Tomkins A. (2003). Household-level technologies to improve the availability and preparation of adequate and safe complementary foods. Fd. Nutr. Bull., 24, 104-115

Mubarak A.E. (2005). Nutritional composition and antinutritional factors of mungbean seeds (Phaseolus aureus) as affected by some home traditional processes. Fd Chem., 89 (4), 489-495
Muhammad R.K. (1990). Nutritive value of sprouted barley. J. Chem. Soc. Pak., 21, 406-408

Muhammed A.A., Javed B.1., Faizullah K.1. and Hamida A.1. (2012). Effect of soaking and malting on the selected nutrient profile of barley. Pak. J. Biochem. Mol. Biol., 44 (1), 18-21

Newport Scientific Method (1998). General Methods for testing starch in the Rapid Visco-Analyser, using thermocline window RVA Super 3. Newport Scientific Pty Ltd, Australia, p. 226

Nzelibe H.C. and Oyeniran A.A. (2001). Phytate levels in different varieties of folio millet (Finger millet, Pearl millet and Sorghum malts). Nig. $J$. Biochem. Mol. Biol., 16, 855-875

Okaka J.C. and Potter N.N. (1979). Physiochemical and functional properties of cowpea powders processed to reduce bean flavour. $J$. $F$ d. Sci., 44 (4), 1235-1240

Oluwole O.B., Kosoko S.B., Owolabi S.O., Adeyoju A.O., Bankole A.O., Ozumba A.U. and Elemo G.N. (2012). Development and production of high protein and energy density beverages from blends of maize (Zea mays), sorghum (Sorghum bicolor) and soybeans (Glycine max) for school aged children: effect of malting period on selected proximate parameters and sensory qualities of developed beverages. Intl. J. Appl. Sci. Technol., 2 (7), 285-292

Omeire J.C., Umeji O.F. and Obasi N.E. (2014). Acceptability of noodles produced from blends of wheat, acha and soyabean flours. NIFOJ, 32 (1), 31-37

Onwurafor E.U., Umego E.C., Uzodinma E.O. and Samuel E.D. (2017). Chemical, functional and sensory properties of sorghum-maize-mungbean malt complementary food. Pak. J. Nutr., 16, 826-834

Pawar V.D. and Machewad G.M. (2006). Changes in availability of iron in barley during malting. J. Fd. Sci. Technol., 43 (1), 28-30

Sandhul K. S. and Lim S. (2007). Digestibility of legume starches as influenced by their physical and structural properties. Carbohydr. Polym., 71, 245-252

Savelkoul F. H.M.G., Van Der Poel A.F.B. and Tamminga S. (1992). The presence and inactivation of trypsin inhibitors, tannins, lectins and amylase inhibitors in legume seeds during germination A review. Plant Fd. Hum. Nutr., 42, 71-85

Scherz H. and Kirchhoff E. (2006). Trace elements in foods: zinc contents of raw foods comparison of data originating from different geographical regions of the World. J. Fd. Comp. Anal., 19, 283-420

Steel R.G. and Torrie J.H. (1980). Principles and Procedures of Statistics. A Biometrical Approach. $2^{\text {nd }}$ ed. McGraw-Hill International, Auckland. pp. 5-102

Takashi S. and Sieb P.A.(1988). Paste and gel properties of prime corn and wheat starches with or without native lipids. Cereal Chem., 65 (6), 474-483

Umunnakwe I.L. (2012). Effect of Malting Periods on the Chemical Composition of Mungbean Flour. A BSc thesis, Department of Food Science \& Technology, University of Nigeria, Nsukka

Uppal V. and Brains K. (2012). Effect of germination periods and hydrothermal treatments on in vitro protein and starch digestibility of germinated legumes. J. Fd. Sci. Technol., 49 (2), 184-191

Wardlaw G.M. and Kessel M.W. (2002). Perspectives in Nutrition. $\left(5^{\text {th }}\right.$ ed.) McGraw Hill Publishers, New Delhi, Seoul, Toronto. p. 450 